\title{
Protective role of paeoniflorin from hydrogen peroxide-mediated oxidative damage in $\mathrm{C} 6$ glial cells
}

\author{
Ah Young Lee ${ }^{1}$ (D) Mi Na Nam ${ }^{2}$ (D) Hyun Young Kim ${ }^{1}$ (D) $\cdot$ Eun Ju Cho ${ }^{2}$ (D)
}

Received: 11 February 2020 / Accepted: 24 March 2020 / Published Online: 30 June 2020

(C) The Korean Society for Applied Biological Chemistry 2020

\begin{abstract}
Oxidative stress is one of the pathogenic mechanisms of various neurodegenerative diseases, such as Alzheimer's disease. Neuroglia, the most abundant cells in the brain, is thought to play an important role in the antioxidant defense system and neuronal metabolic support against neurotoxicity and oxidative stress. We investigated the protective effect of paeoniflorin $(\mathrm{PF})$ against oxidative stress in $\mathrm{C} 6$ glial cells. Exposure of C6 glial cells to hydrogen peroxide $\left(\mathrm{H}_{2} \mathrm{O}_{2}, 500 \mu \mathrm{M}\right)$ significantly decreased cell viability and increased amounts of lactate dehydrogenase (LDH) release, indicating $\mathrm{H}_{2} \mathrm{O}_{2}$-induced cellular damage. However, treatment with $\mathrm{PF}$ significantly attenuated $\mathrm{H}_{2} \mathrm{O}_{2}$-induced cell death as shown by increased cell survival and decreased LDH release. The $\mathrm{H}_{2} \mathrm{O}_{2-}$ stimulated reactive oxygen species production was also suppressed, and it may be associated with improvement of superoxide dismutase activity by treatment with PF. In addition, an increase in ratio of $\mathrm{Bcl}-2 / \mathrm{Bax}$ protein expression was observed after treatment with PF. In particular, the down-stream of the apoptotic signaling pathway was inhibited in the presence of PF, mostly by reduction of cleaved-poly ADP ribose polymerase, cleaved caspase-3, and -9 protein expression. Furthermore, $\mathrm{H}_{2} \mathrm{O}_{2}$-induced phosphorylation of c-Jun N-terminal kinase and extracellular signal-regulated kinase $1 / 2$ was attenuated by treatment with PF. Taken together, neuroprotective effect of PF against oxidative stress probably result from the regulation of apoptotic pathway in C6 glial cells. In conclusion, our findings suggest that PF may be a potent therapeutic agent for neurodegenerative disorders.
\end{abstract}

Eun Ju Cho $(\bowtie)$

E-mail: ejcho@pusan.ac.kr

${ }^{1}$ Department of Food Science, Gyeongnam National University of Science and Technology, Jinju 52725, Republic of Korea

${ }^{2}$ Department of Food Science and Nutrition \& Kimchi Research Institute, Pusan National University, Busan 46241, Republic of Korea

This is an Open Access article distributed under the terms of the Creative Commons Attribution Non-Commercial License (http://creativecommons. org/licenses/by-nc/3.0/) which permits unrestricted non-commercial use, distribution, and reproduction in any medium, provided the original work is properly cited.
Keywords Hydrogen peroxide - Neurodegenerative diseases · Neuroglia $\cdot$ Oxidative stress $\cdot$ Paeoniflorin

\section{Introduction}

Oxidative stress-induced cell death in the brain has been implicated in physiological and pathological processes of several neurodegenerative diseases, such as Alzheimer's disease (AD), Parkinson's disease, and cerebral ischemia [1,2]. There has been growing evidences of oxidative stress occurring from imbalance between prooxidant production and antioxidant defense in the body. One of the major reactive oxygen species (ROS) is hydrogen peroxide $\left(\mathrm{H}_{2} \mathrm{O}_{2}\right)$. Although $\mathrm{H}_{2} \mathrm{O}_{2}$ is not a free radical, it can enter the cellular membrane and produce toxic hydroxyl radical, which attacks proteins, lipid membranes, or nucleic acids, leading to cellular dysfunction and apoptosis in various types of cells [3].

Glial cells play an important role in the antioxidant defense in central nervous system (CNS) and modulation of synaptic functions [4]. According to previous report, glial cells contribute to protection of brain by up-regulation of glutathione synthesis, which acts as an antioxidant in the brain [5]. In addition, glial cells can promote the amyloid $\beta$ clearance and prevent neuronal cell death in AD brain [6]. When glial cells are stimulated with oxidative stress or neurotoxic factors, it may disrupt the homeostasis of the CNS and exacerbate AD progression [7]. In this regard, protection from oxidative stress and regulation of glial cell death may be an important target in the prevention or treatment of neurodegenerative diseases. Recently, attention has been focused on natural antioxidants that can scavenge free radicals and prevent free radicals-induced apoptotic cell death.

Paeoniflorin (PF), a main monoterpene glycoside of Paeoniae Radix, has been known to have beneficial effects on the brain health. Previous studies suggested that PF attenuated behavioral and cognitive impairment in animal models [8,9]. Mao et al. [10] also demonstrated that $\mathrm{PF}$ protects $\mathrm{PC} 12$ neuronal cells against 
glutamate-induced neurotoxicity via attenuating oxidative stress. The neuroprotective properties of PF may be related to regulation of oxidative stress and inflammatory responses in vitro and in vivo $[11,12]$. However, protective effect of $\mathrm{PF}$ in $\mathrm{H}_{2} \mathrm{O}_{2}$-induced glial cell death and the underlying mechanisms have not been studied yet. Therefore, the aim of this present study was to investigate the effect of PF on cell viability, lactate dehydrogenase (LDH) release, ROS production, and antioxidant enzyme activity in $\mathrm{H}_{2} \mathrm{O}_{2}$-treated C6 glial cells. Furthermore, the underlying mechanism of PF on glial cell death was examined.

\section{Materials and Methods}

\section{Instruments and reagents}

PF (purity $>98 \%$, MW: 480.5 ) was obtained from Cayman Chemical Co. (Ann Arbor, MI, USA). Prior to use, PF was freshly prepared as a stock solution in dimethyl sulfoxide (DMSO). For cell culture, Dulbecco's modified eagle's medium (DMEM), fetal bovine serum (FBS) and penicillin/streptomycin were obtained from Welgene (Daegu, Korea). The $\mathrm{H}_{2} \mathrm{O}_{2}$ was purchased from Junsei chemical Co. (Tokyo, Japan). The dichlorofluorescin diacetate (DCFH-DA) was from Sigma Chemical Co. (St Louis, MO, USA). Radio-immunoprecipitation assay (RIPA) buffer, 30\% acrylamide bis solution, and protein size markers were supplied from Elpis Biotech (Daejeon, Korea).

\section{Cell culture}

C6 glial cells used in this study were obtained from KCLB (Korean Cell Line Bank, Seoul, Korea). Cells were cultured with DMEM, $10 \%$ FBS, and $1 \%$ penicillin/streptomycin in a humidified $\mathrm{CO}_{2}$ incubator $\left(37^{\circ} \mathrm{C}, 5 \%\right)$.

\section{3-(4,5-dimethylthiazol-2-yl)-2,5-diphenyl tetrazolium bromide (MTT) assay}

According to our preliminary research, treatment with PF (at a range of concentration from 0.1 to $10 \mu \mathrm{g} / \mathrm{mL}$ ) did not affect cellular conditions in C6 glial cells. However, $25 \mu \mathrm{g} / \mathrm{mL}$ of PF significantly decreased cell viability compared to normal group, indicating that $\mathrm{PF}$ has toxic effect for $\mathrm{C} 6$ glial cells at the concentration of $25 \mu \mathrm{g} / \mathrm{mL}$. Based on this finding, we decided to further investigate the effect of $\mathrm{PF}$ at a concentration range of 1$10 \mu \mathrm{g} / \mathrm{mL}$. At confluence, the cells were seeded at a density of $5 \times 10^{4}$ cells $/ \mathrm{mL}$ in 96-well plate overnight. After incubation, different concentrations of PF $(1,5$, and $10 \mu \mathrm{g} / \mathrm{mL})$ were added to the culture plate and incubated for $4 \mathrm{~h}$, and then added with $\mathrm{H}_{2} \mathrm{O}_{2}$ $(500 \mu \mathrm{M})$. After incubation for $24 \mathrm{~h}$, MTT solution (Sigma Chemical Co.) was added to each 96-well plate and incubated for $4 \mathrm{~h}$ at $37{ }^{\circ} \mathrm{C}$. Then, the medium containing MTT was removed. Formazan crystals in the viable cells were solubilized with DMSO, and the absorbance of each well was read at $540 \mathrm{~nm}$, using a microplate reader [13].

\section{LDH release assay}

The levels of LDH release were investigated by using a LDH cytotoxicity kit (Takara Bio, Shiga, Japan). In brief, C6 glial cells were seeded in 96-well plate at a density of $5 \times 10^{4}$ cells $/ \mathrm{mL}$ overnight. Different concentrations of PF $(1,5$, and $10 \mu \mathrm{g} / \mathrm{mL})$ were treated for $4 \mathrm{~h}$, and then added with $\mathrm{H}_{2} \mathrm{O}_{2}(500 \mu \mathrm{M})$ for $24 \mathrm{~h}$. The supernatant $(100 \mu \mathrm{L})$ was collected and mixed with reaction solution $(100 \mu \mathrm{L})$. After incubation for $30 \mathrm{~min}$ at room temperature, the absorbance of each well was detected wavelength at $490 \mathrm{~nm}$, using a microplate reader [14].

\section{DCFH-DA assay}

Intracellular levels of ROS were measured using the method of DCFH-DA assay, as described by Cathcart et al. [15]. C6 glial cells were plated at density of $5 \times 10^{4}$ cells $/ \mathrm{mL}$ in 96 -well plate overnight. The cells were pre-treated with PF (1, 5, and $10 \mu \mathrm{g} /$ $\mathrm{mL})$ for $4 \mathrm{~h}$, and further incubated with $\mathrm{H}_{2} \mathrm{O}_{2}(500 \mu \mathrm{M})$ for $24 \mathrm{~h}$. After that, $80 \mu \mathrm{M}$ DCFH-DA were added and incubated at $37{ }^{\circ} \mathrm{C}$ for $30 \mathrm{~min}$. The fluorescence was read with a wavelength at 480 $\mathrm{nm}$ excitation and a wavelength at $535 \mathrm{~nm}$ emission for $60 \mathrm{~min}$, using a fluorescence microplate reader (BMG LABTECH, Ortenberg, Germany).

\section{Superoxide dismutase (SOD) enzyme activity}

The cells were collected by centrifugation, and the cell pellets were sonicated in cold PBS. Cell lysates was centrifugated at $10,000 \times \mathrm{g}$ for $15 \mathrm{~min}$, and supernatant was assayed for SOD activity according to manufacturer instructions using the commercial SOD kit (Sigma Chemical Co.). The absorbance was determined at $440 \mathrm{~nm}$, using a microplate reader.

\section{Western blotting}

The protein extracts from C6 glial cells for Western blot were collected by using RIPA buffer and $1 \times$ protease inhibitor cocktail. The protein concentration of whole-cell lysates were quantified using bovine serum albumin solution. Protein samples were subjected to electrophoresis in $10-13 \%$ sodium dodecyl sulfate polyacrylamide gel electrophoresis for protein separation and transferred to polyvinylidene fluoride (PVDF) membrane (Millipore, Billerica, MA, USA). For blocking, the PVDF membrane was placed in 5\% skimmed milk solution for $1 \mathrm{~h}$ at room temperature, and incubated at $4{ }^{\circ} \mathrm{C}$ overnight with the primary antibody [cleaved caspase-9 (1:1000, \#9508, Cell signaling, Beverly, MA, USA), cleaved caspase-3 (1:1000, \#9661, Cell signaling), poly ADP ribose polymerase (PARP, 1:1000, \#9532, Cell signaling), Bax (1:200, \#sc-493, Santa Cruz Biotechnology, Santa Cruz, CA, USA), Bcl-2 (1:200, \#sc-492, Santa Cruz Biotechnology), phospho c-Jun N-terminal kinase (phospho JNK, 1:200, \#4668, Santa Cruz Biotechnology), phospho extracellular signal-regulated kinase1/2 (phospho ERK1/2, 1:200, \#4370, Santa Cruz Biotechnology), and $\beta$-actin (1:1000, \#8457, Cell signaling)]. After incubation, the membrane was washed with TBS-T (Tris-base buffered containing 
$0.1 \%$ Tween 20) and incubated with the appropriate HRPconjugated secondary antibodies. Membranes were visualized using enhanced chemiluminescence kit (Bio-Rad, Hercules, CA, USA) and intensity of Western bands was detected by chemiluminescent imaging system (Davinci Chemi, Seoul, Korea).

\section{Statistical analysis}

All data in the present study were shown as mean values \pm standard deviation (SD). Statistical significance was determined using one-way analysis of variance (ANOVA), followed by Duncan's post-hoc tests for multiple comparisons using SPSS statistics software program, version 23 (IBM SPSS Statistics, Chicago, IL, USA). Statistically significance was set at $p<0.05$.

\section{Results}

Effects of $\mathrm{PF}$ on cell viability in $\mathrm{H}_{2} \mathrm{O}_{2}$-induced $\mathrm{C} 6$ glial cells To investigate the effect of PF on cytotoxicity in $\mathrm{C} 6$ glial cells induced by $\mathrm{H}_{2} \mathrm{O}_{2}$, we examined cell viability using MTT assay. As shown in Fig. 1, exposure of $\mathrm{C} 6$ glial cells to $\mathrm{H}_{2} \mathrm{O}_{2}$ significantly decreased the cell viability $(63.71 \%)$, compared to that of normal group $(100 \%)$. However, cell viability was significantly higher in cells treated with PF (5 and $10 \mu \mathrm{g} / \mathrm{mL}$ ), showing 75.38 and $78.15 \%$, respectively. This observation suggests that $\mathrm{PF}$ has protective effect from oxidative stress-induced glial cell death.

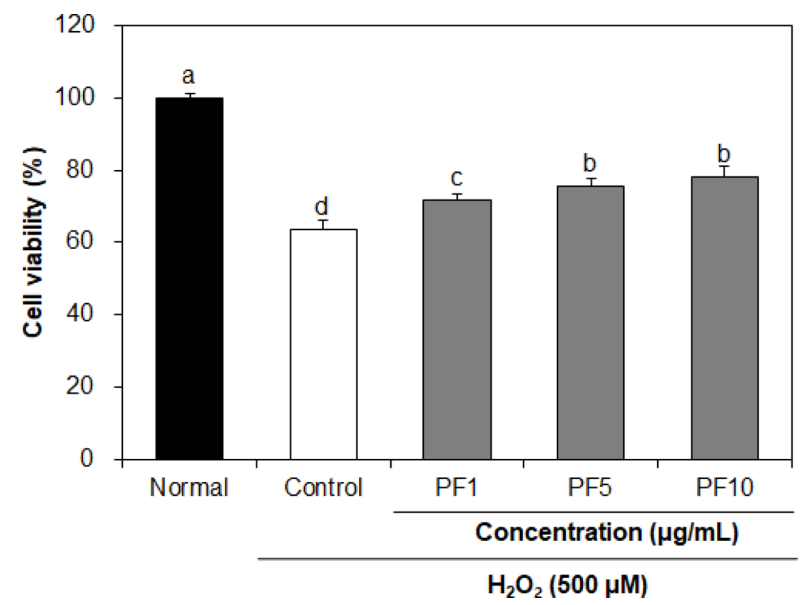

Fig. 1 Effect of PF on cell viability in $\mathrm{H}_{2} \mathrm{O}_{2}$-induced $\mathrm{C} 6$ glial cells. The C6 glial cells were pretreated with different concentrations of PF $(1,5,10$ $\mu \mathrm{g} / \mathrm{mL}$ ) for $4 \mathrm{~h}$ and further incubated in the presence of $500 \mu \mathrm{M} \mathrm{H}_{2} \mathrm{O}_{2}$ for $24 \mathrm{~h}$. Values are expressed as mean $\pm \mathrm{SD}$. ${ }^{\mathrm{a}-\mathrm{d}}$ Means with different letters indicate significant differences $(p<0.05)$ as determined by Duncan's multiple range test. 'Normal' group represents the non-treated cells, 'Control' group represents the $\mathrm{H}_{2} \mathrm{O}_{2}$-treated cells, 'PF1', 'PF5', or 'PF10' groups represent the three concentrations of paeoniflorin treatment $(1,5$, $10 \mu \mathrm{g} / \mathrm{mL}$ ) in $\mathrm{H}_{2} \mathrm{O}_{2}$-treated cells
Effects of $\mathrm{PF}$ on $\mathrm{LDH}$ release in $\mathrm{H}_{2} \mathrm{O}_{2}$-induced $\mathrm{C6}$ glial cells To assess the effect of PF on glial cell damage, we examined the changes in LDH release induced by $\mathrm{H}_{2} \mathrm{O}_{2}$ in $\mathrm{C} 6$ glial cells. As presented in Fig. 2, $\mathrm{H}_{2} \mathrm{O}_{2}$ exposure significantly increased $\mathrm{LDH}$ release $(30.40 \%)$ compared with the normal group (1.64\%). However, $\mathrm{PF}$ inhibited $\mathrm{H}_{2} \mathrm{O}_{2}$-induced cellular damage; treatment with $10 \mu \mathrm{g} / \mathrm{mL}$ of PF resulted in LDH release of $25.88 \%$. This data indicates that $\mathrm{PF}$ prevents $\mathrm{C} 6$ glial cells from oxidative stress induced by $\mathrm{H}_{2} \mathrm{O}_{2}$.

Effects of $\mathrm{PF}$ on ROS production in $\mathrm{H}_{2} \mathrm{O}_{2}$-induced $\mathrm{C} 6$ glial cells To evaluate the levels of intracellular $\mathrm{ROS}$ in $\mathrm{H}_{2} \mathrm{O}_{2}$-induced $\mathrm{C} 6$ glial cells, the DCFH-DA fluorescence was assessed. Our result indicated that $\mathrm{H}_{2} \mathrm{O}_{2}$-treated control group had a significant increase in DCF fluorescence intensity when compared to that in the normal group (Fig. 3). However, the fluorescence intensity was significantly reduced in the PF-treated group. In particular, 10 $\mu \mathrm{g} / \mathrm{mL}$ of PF group had the strongest ROS inhibitory effect among the treatment groups. Therefore, this result suggests that PF could inhibit ROS generation induced by $\mathrm{H}_{2} \mathrm{O}_{2}$ in $\mathrm{C} 6$ glial cells.

Effects of PF on SOD activity in $\mathrm{H}_{2} \mathrm{O}_{2}$-induced $\mathrm{C6}$ glial cells We measured the SOD activity to determine whether antioxidant enzyme activity was involved in the protective effect of PF against $\mathrm{H}_{2} \mathrm{O}_{2}$-induced oxidative and neurotoxic conditions. As shown in Fig. 4, our results revealed that $\mathrm{H}_{2} \mathrm{O}_{2}$ treatment reduced SOD activity by $73.76 \%$, in comparison to normal group (100\%).

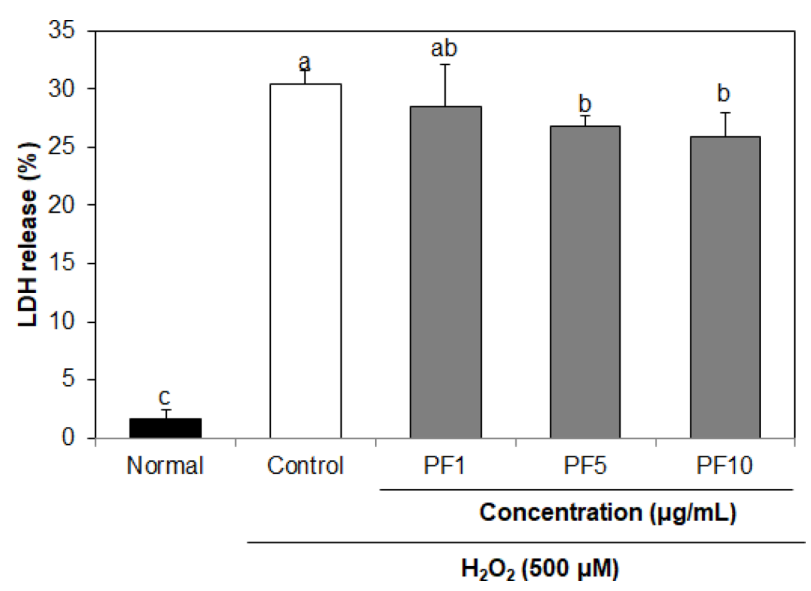

Fig. 2 Effect of PF on LDH release in $\mathrm{H}_{2} \mathrm{O}_{2}$-induced $\mathrm{C} 6$ glial cells. The C6 glial cells were pretreated with different concentrations of PF $(1,5$, $10 \mu \mathrm{g} / \mathrm{mL}$ ) for $4 \mathrm{~h}$ and further incubated in the presence of $500 \mu \mathrm{M} \mathrm{H}_{2} \mathrm{O}_{2}$ for $24 \mathrm{~h}$. Values are expressed as mean $\pm \mathrm{SD}$. ${ }^{\mathrm{a}-\mathrm{c}}$ Means with different letters indicate significant differences $(p<0.05)$ as determined by Duncan's multiple range test. 'Normal' group represents the non-treated cells, 'Control' group represents the $\mathrm{H}_{2} \mathrm{O}_{2}$-treated cells, 'PF1', 'PF5', or 'PF10' groups represent the three concentrations of paeoniflorin treatment $(1,5,10 \mu \mathrm{g} / \mathrm{mL})$ in $\mathrm{H}_{2} \mathrm{O}_{2}$-treated cells 

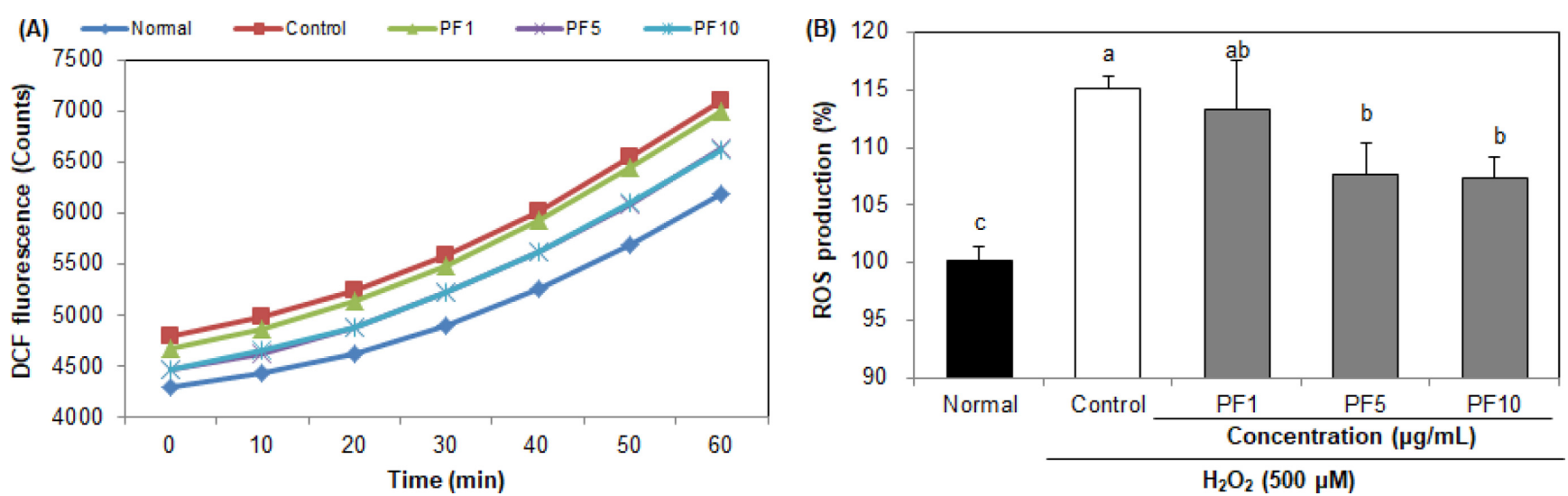

Fig. 3 Effect of PF on ROS production in $\mathrm{H}_{2} \mathrm{O}_{2}$-induced $\mathrm{C} 6$ glial cells. Time course of changes in intensity of DCF fluorescence with PF treatment at different time points $(0-60 \mathrm{~min})(\mathrm{A})$. Production of ROS in the $\mathrm{H}_{2} \mathrm{O}_{2}$-induced $\mathrm{C} 6$ glial cells treated with $\mathrm{PF}$ at 60 min (B). The C6 glial cells were pretreated with different concentrations of $\mathrm{PF}(1,5,10 \mu \mathrm{g} / \mathrm{mL})$ for $4 \mathrm{~h}$ and further incubated in the presence of $500 \mu \mathrm{M} \mathrm{H}_{2} \mathrm{O}_{2}$ for $24 \mathrm{~h}$. Values are expressed as mean $\pm \mathrm{SD}$. ${ }^{\mathrm{a}-\mathrm{c}}$ Means with different letters indicate significant differences $(p<0.05)$ as determined by Duncan's multiple range test. 'Normal' group represents the non-treated cells, 'Control' group represents the $\mathrm{H}_{2} \mathrm{O}_{2}$-treated cells, 'PF1', 'PF5', or 'PF10' groups represent the three concentrations of paeoniflorin treatment $(1,5,10 \mu \mathrm{g} / \mathrm{mL})$ in $\mathrm{H}_{2} \mathrm{O}_{2}$-treated cells

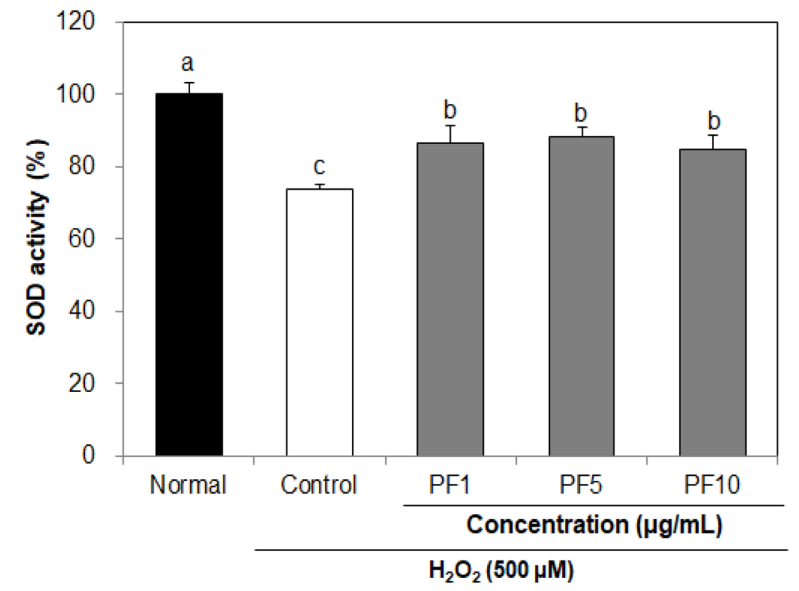

Fig. 4 Effect of PF on SOD enzyme activity in $\mathrm{H}_{2} \mathrm{O}_{2}$-induced $\mathrm{C} 6$ glial cells. The $\mathrm{C} 6$ glial cells were pretreated with different concentrations of $\mathrm{PF}(1,5,10 \mu \mathrm{g} / \mathrm{mL})$ for $4 \mathrm{~h}$ and further incubated in the presence of 500 $\mu \mathrm{M} \mathrm{H}_{2} \mathrm{O}_{2}$ for $24 \mathrm{~h}$. Values are expressed as mean $\pm \mathrm{SD}$. ${ }^{\mathrm{a}-\mathrm{c}}$ Means with different letters indicate significant differences $(p<0.05)$ as determined by Duncan's multiple range test. 'Normal' group represents the nontreated cells, 'Control' group represents the $\mathrm{H}_{2} \mathrm{O}_{2}$-treated cells, 'PF1', 'PF5', or 'PF10' groups represent the three concentrations of paeoniflorin treatment $(1,5,10 \mu \mathrm{g} / \mathrm{mL})$ in $\mathrm{H}_{2} \mathrm{O}_{2}$-treated cells

Meanwhile, $\mathrm{PF}(1,5$, and $10 \mu \mathrm{g} / \mathrm{mL})$ treatments led to an increase in SOD activity with over $80 \%$. This finding supports that inhibitory effect of PF on ROS production may be associated with SOD activity in $\mathrm{H}_{2} \mathrm{O}_{2}$-treated $\mathrm{C} 6$ glial cells.

Effects of PF on the levels of Bcl-2/Bax, cleaved caspase-9, -3, and cleaved PARP protein expression in $\mathrm{H}_{2} \mathrm{O}_{2}$-induced $\mathrm{C} 6$ glial cells

In order to investigate the protective effect of PF on glial cell death against $\mathrm{H}_{2} \mathrm{O}_{2}$, we identified the underlying mechanisms by Western blotting. In our results, the Bcl-2/Bax ratio was significantly lower in cells treated with $\mathrm{H}_{2} \mathrm{O}_{2}$, whereas this decrease was prevented by treatments with PF (Fig. 5A). To further examine whether PF prevents cell death by the regulation of caspase cascade, we analyzed the levels of cleaved caspase-9, -3, and cleaved PARP protein expression. The expressions of cleaved caspase-9 and -3 proteins were up-regulated in cells exposed to $\mathrm{H}_{2} \mathrm{O}_{2}$, compared to non-exposed cells (Fig. 5B). However, treatment with $\mathrm{PF}(5$ and $10 \mu \mathrm{g} / \mathrm{mL}$ ) significantly reduced the cleaved caspase- 9 and -3 expressions induced by $\mathrm{H}_{2} \mathrm{O}_{2}$. In particular, $10 \mu \mathrm{g} / \mathrm{mL}$ of PF remarkably inhibited PARP cleavage, which is consistent with the suppression of caspase-9 and -3 expressions. These results suggest that $\mathrm{PF}$ could protect $\mathrm{H}_{2} \mathrm{O}_{2}$ induced $\mathrm{C} 6$ cell death by down-regulation of apoptotic signaling pathway.

Effects of PF on the levels of phospho JNK and phospho ERK1/2 protein expression in $\mathrm{H}_{2} \mathrm{O}_{2}$-induced $\mathrm{C} 6$ glial cells

To confirm the role of PF on mitogen-activated protein kinase (MAPK) signaling pathway, the levels of phospho JNK and phospho ERK1/2 protein expression were determined by Western blotting. Our results showed that exposure of C6 glial cells to 500 $\mu \mathrm{M} \mathrm{H}_{2} \mathrm{O}_{2}$ caused a significant increase in phospho JNK (Fig. 6A) and phospho ERK1/2 (Fig. 6B) protein expression, whereas the low levels of these protein expression were observed in PF-treated groups, when compared to control group. Especially, $10 \mu \mathrm{g} / \mathrm{mL}$ of $\mathrm{PF}$ significantly reduced $\mathrm{H}_{2} \mathrm{O}_{2}$-mediated $\mathrm{JNK}$ phosphorylation, which was similar to normal group. These findings suggest that neuroprotective effect of PF may also be due to inactivation of JNK and ERK1/2 phosphorylation induced by oxidative stress. 
(A)

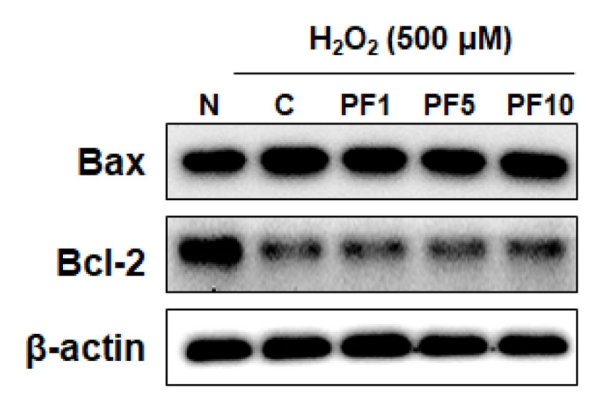

(B)
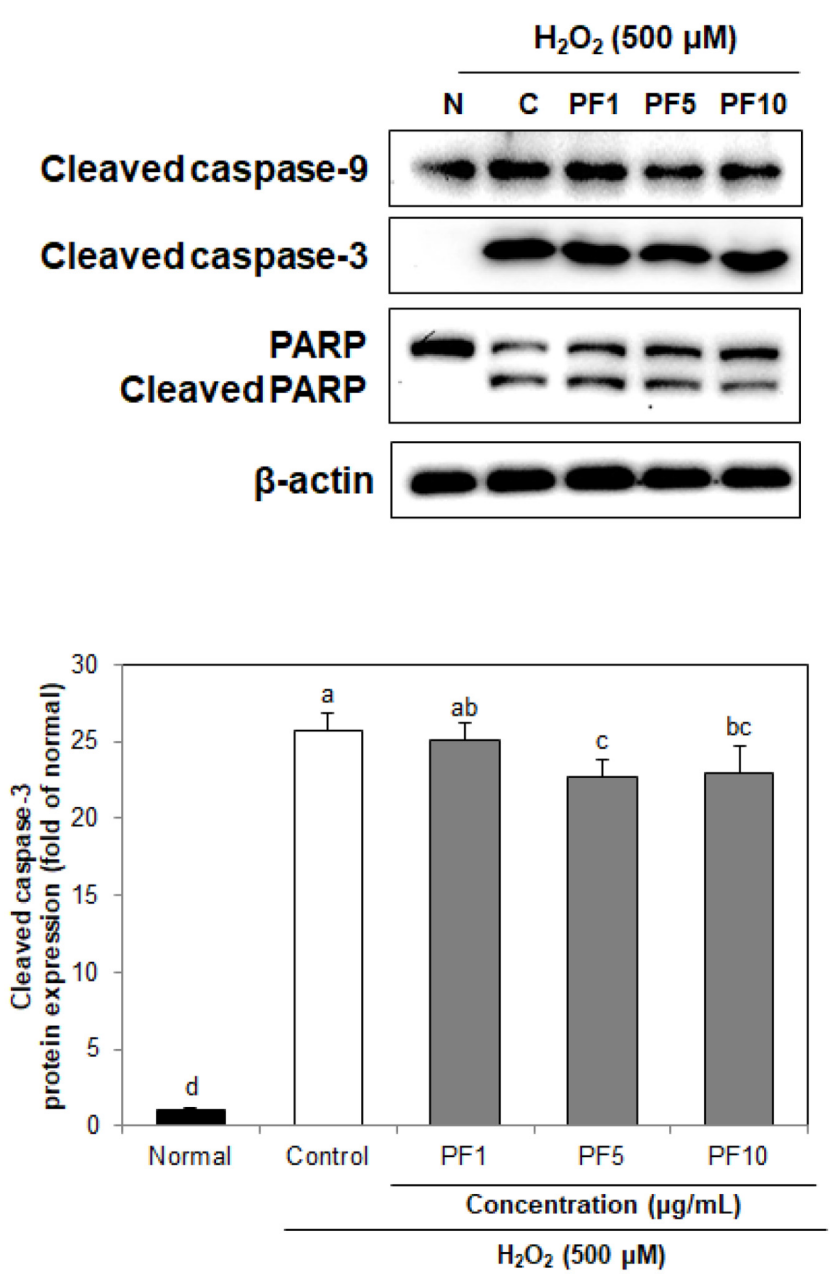
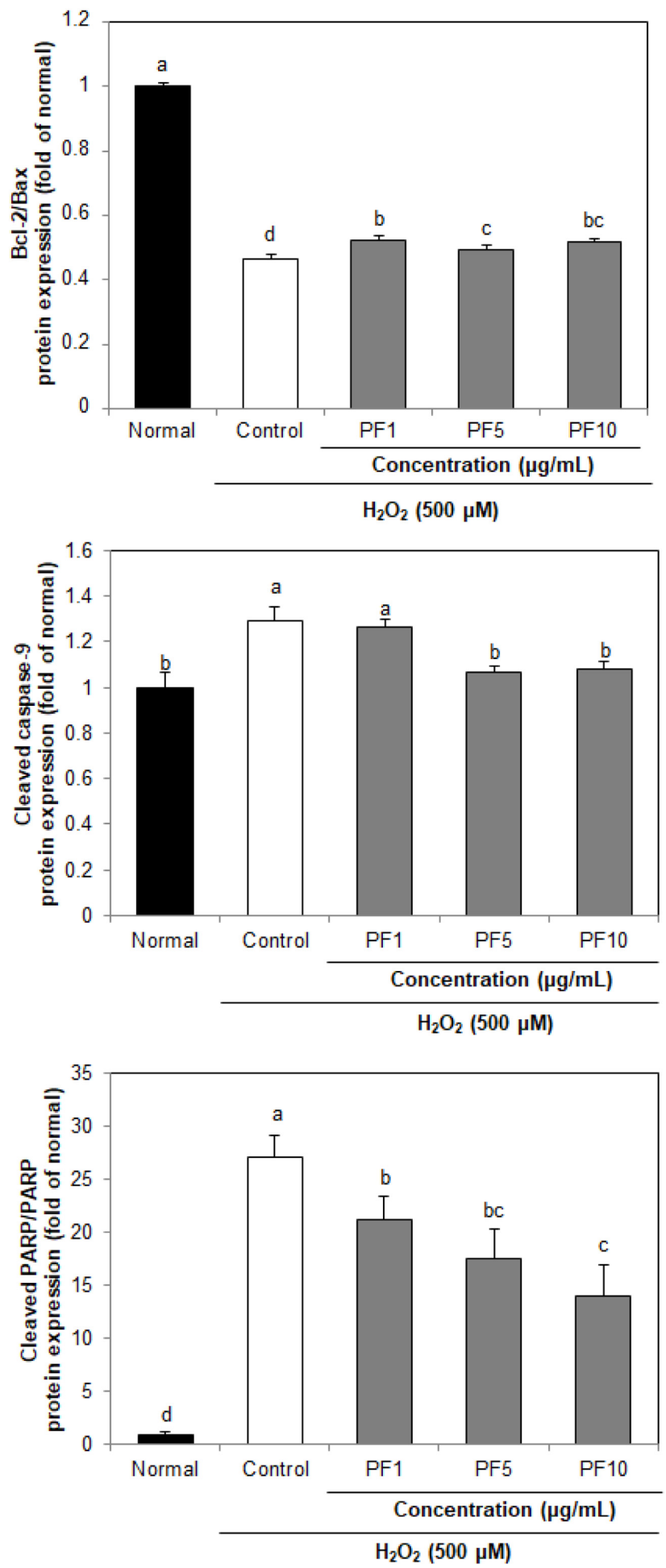

Fig. 5 Effect of PF on the levels of Bcl-2/Bax (A), cleaved caspase-9, -3 and cleaved PARP (B) protein expression in $\mathrm{H}_{2} \mathrm{O}_{2}$-induced $\mathrm{C} 6$ glial cells. The C6 glial cells were pretreated with different concentrations of $\mathrm{PF}(1,5,10 \mu \mathrm{g} / \mathrm{mL})$ for $4 \mathrm{~h}$ and further incubated in the presence of $500 \mu \mathrm{M} \mathrm{H}_{2} \mathrm{O}_{2}$ for 24 h. Images of band are from a representative experiment and bars represent the mean $\pm \mathrm{SD}(\mathrm{n}=3) .{ }^{\mathrm{a}-\mathrm{d}}$ Means with different letters indicate significant differences $(p<0.05)$ as determined by Duncan's multiple range test. $\beta$-Actin was used as a loading control. 'Normal' group represents the non-treated cells, 'Control' group represents the $\mathrm{H}_{2} \mathrm{O}_{2}$-treated cells, 'PF1', 'PF5', or 'PF10' groups represent the three concentrations of paeoniflorin treatment (1, $5,10 \mu \mathrm{g} / \mathrm{mL}$ ) in $\mathrm{H}_{2} \mathrm{O}_{2}$-treated cells 
(A)

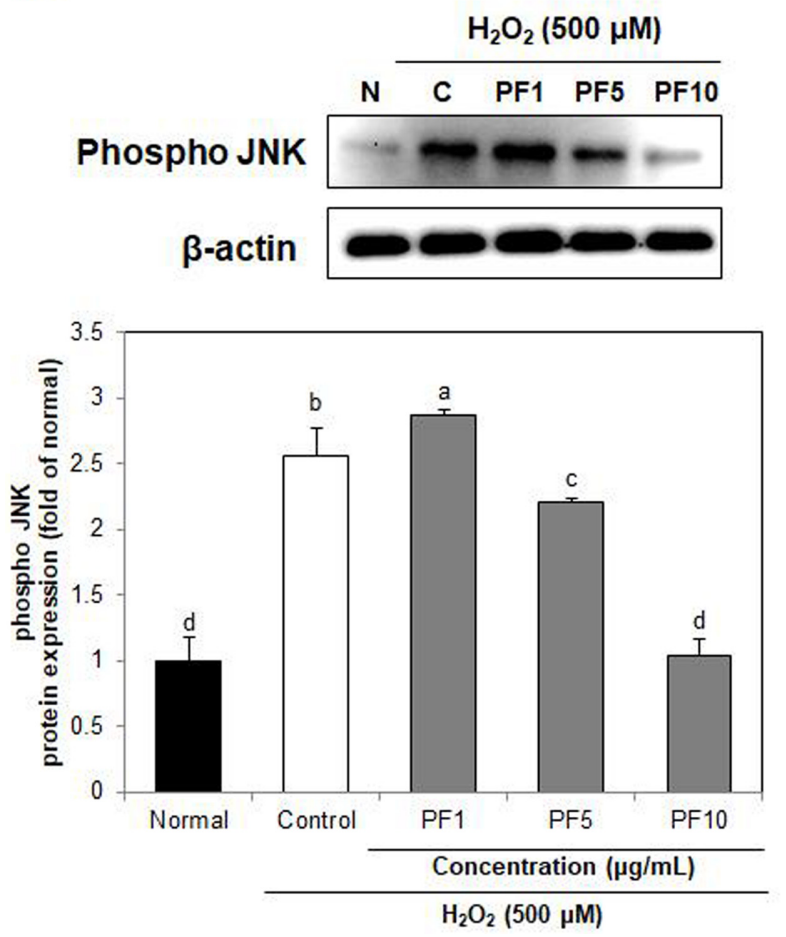

(B)
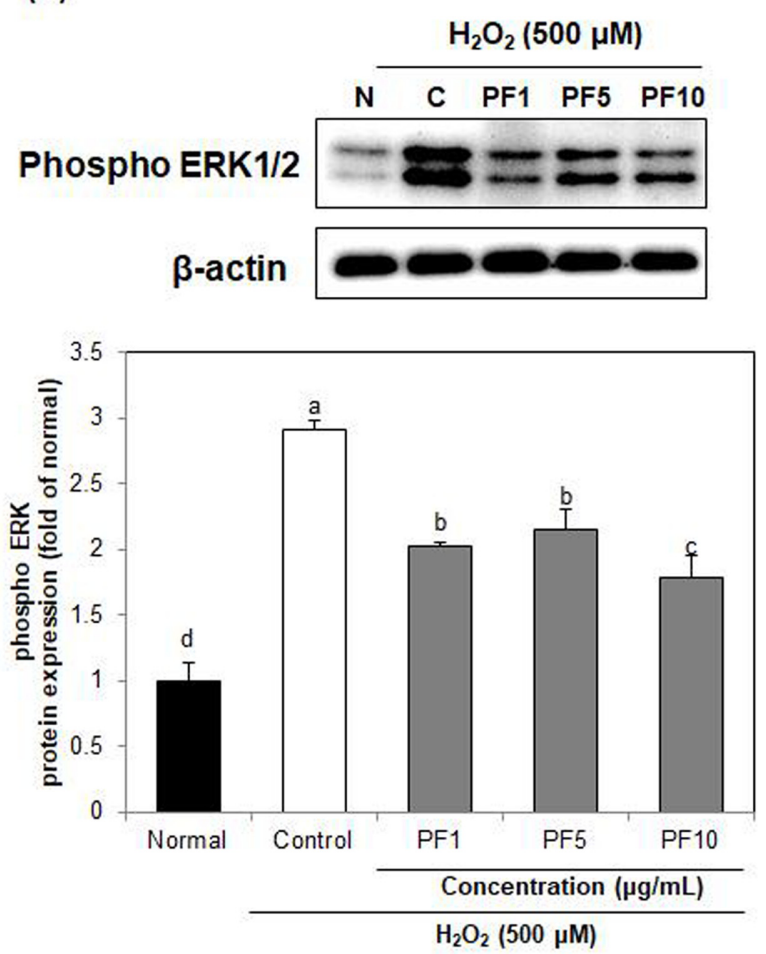

Fig. 6 Effect of PF on the levels of phospho JNK (A) and phospho ERK1/2 (B) protein expression in $\mathrm{H}_{2} \mathrm{O}_{2}$-induced C6 glial cells. The C6 glial cells were pretreated with different concentrations of $\mathrm{PF}(1,5,10 \mu \mathrm{g} / \mathrm{mL})$ for $4 \mathrm{~h}$ and further incubated in the presence of $500 \mathrm{iM} \mathrm{H}_{2} \mathrm{O}_{2}$ for $24 \mathrm{~h}$. Images of band are from a representative experiment and bars represent the mean $\pm \mathrm{SD}(\mathrm{n}=3)$. ${ }^{\mathrm{a}-\mathrm{d}}$ Means with different letters indicate significant differences $(p<0.05)$ as determined by Duncan's multiple range test. $\beta$-Actin was used as a loading control. 'Normal' group represents the non-treated cells, 'Control' group represents the $\mathrm{H}_{2} \mathrm{O}_{2}$-treated cells, 'PF1', 'PF5', or 'PF10' groups represent the three concentrations of paeoniflorin treatment (1, 5, $10 \mu \mathrm{g} / \mathrm{mL})$ in $\mathrm{H}_{2} \mathrm{O}_{2}$-treated cells

\section{Discussion}

Moderate concentrations of ROS play an important physiological role in the body. However, high levels of ROS and low levels of antioxidant enzyme activity in the brain result in oxidative damage, which is a major cause of neurodegenerative disease, such as $\mathrm{AD}$ [16]. In addition to oxidative stress, $\mathrm{AD}$ is characterized by mitochondrial dysfunction and increased sensitivity to apoptosis in the neuronal and glial cells [17]. Glial cells are the most abundant cell types in the brain, and they support and protect neurons against oxidative stress. Moreover, glial cells are responsible for maintaining the homeostasis in the brain through modulation of neurotransmission and secretion of growth factors [18]. They are also believed to play a critical role in the neuronal function mediated by mobilizing nutrients to the neurons and removing the waste materials from neurons [19]. They influence neuronal survival through regulation of free radical scavenging and production of cytokines [20], thus dysfunction of glial cells affects neuronal cell viability. Oxidative stress stimulates glial cells and induces secretion of pro-inflammatory cytokines, causing cellular dysfunction and progression of inflammatory responses [21]. Delacourte [23] also demonstrated that the changes in shape and function of glial cells results from certain gene expression and secondary reaction might be a key element in the pathogenesis of neurodegenerative disorders.

Oxygen radicals can cause cellular damage to structure and functions, which in the end can lead to cell death. Among them, $\mathrm{H}_{2} \mathrm{O}_{2}$ can enter the cells rapidly and induce the high degree of oxidative stress because of its high membrane permeability [24]. Glial cells also can be affected by $\mathrm{H}_{2} \mathrm{O}_{2}$ and undergo degeneration, resulting in apoptotic cell death [25]. In previous study, phosphatidylinositol 3 kinase/protein kinase B signaling pathway is activated by treatment with $\mathrm{PF}$ and plays a protective role in neural progenitor cell death induced by $\mathrm{H}_{2} \mathrm{O}_{2}$ [26]. In addition, $\mathrm{PF}$ treatment significantly reduced $\mathrm{H}_{2} \mathrm{O}_{2}$-mediated neuronal apoptosis and intracellular ROS accumulation by suppression of neuroinflammation in PC12 cells [27]. However, whether PF possesses protective activity in $\mathrm{C} 6$ glial cells against the $\mathrm{H}_{2} \mathrm{O}_{2}$-induced cell death is not known. Taken together, we focused on the protective effect and mechanisms of PF from oxidative stress using glial cells.

Treatment of $\mathrm{H}_{2} \mathrm{O}_{2}$ has been reported to induce cytotoxicity in glial cultures, and to increase LDH release as well as ROS production, which could be blocked by using antioxidants [28, 
29]. Our results of MTT and LDH assays revealed that treatment with $500 \mu \mathrm{M} \mathrm{H}_{2} \mathrm{O}_{2}$ significantly decreased cell viability and accelerated the amounts of LDH release. However, treatment with PF ( 5 and $10 \mu \mathrm{g} / \mathrm{mL}$ ) was observed to remarkably increased cell viability and decreased LDH release against $\mathrm{H}_{2} \mathrm{O}_{2}$. $\mathrm{Li}$ and $\mathrm{Li}$ [27] also reported that $\mathrm{PF}$ protected the neuronal cells against $\mathrm{H}_{2} \mathrm{O}_{2-}$ induced oxidative injury, as shown by increasing cell viability and attenuating LDH release. These results demonstrate that PF plays a protective role in $\mathrm{C} 6$ glial cells against $\mathrm{H}_{2} \mathrm{O}_{2}$-induced cellular damage.

Increased ROS production following $\mathrm{H}_{2} \mathrm{O}_{2}$ treatment has already been reported to cause cellular dysfunction and reduction of antioxidant defense system in the brain [30,31]. To evaluate the levels of intracellular ROS in $\mathrm{H}_{2} \mathrm{O}_{2}$-induced $\mathrm{C} 6$ glial cells, the DCFH-DA fluorescence was assessed. After exposure to $\mathrm{H}_{2} \mathrm{O}_{2}$, DCFDA is oxidized into 2,7-dichlorofluorescein (DCF), which can be measured by fluorescence microplate reader. From our results, it is evident that $\mathrm{H}_{2} \mathrm{O}_{2}$ induces cellular damage by increasing the production of ROS, whereas treatment with PF prior to $\mathrm{H}_{2} \mathrm{O}_{2}$ exposure significantly suppressed ROS levels. Previously, PF has been shown to scavenge ROS in an extracellular environment against oxidative stress [32]. Moreover, PF has been shown radical scavenging activity, such as hydroxyl radical and peroxy radical, which was similar to the effect of major antioxidant, glutathione [33], suggesting that $\mathrm{PF}$ is responsible for protection from ROS-mediated cellular damage. On the basis of these evidences, $\mathrm{PF}$ is considered as a promising antioxidant with radical scavenging effect.

Excessive production of ROS can induce brain damage, which could be eliminated by several antioxidant enzymes. Glial cells contain high levels of antioxidant enzymes, including SOD, catalase, glutathione peroxidase (GPx). However, SOD enzyme is reduced and inactivated by oxidative stress, and deficiency of SOD activity could result in accumulation of toxic $\mathrm{O}_{2}^{-}$radicals, leading to additional cellular damage [34]. Therefore, we hypothesized that the protective mechanism of PF on $\mathrm{C} 6$ glial cells against $\mathrm{H}_{2} \mathrm{O}_{2}$-induced oxidative damage may be due to its up-regulation of cellular antioxidant system, such as SOD activity, that is capable of scavenging ROS. Li et al. [35] reported that PF treatment inhibited production of free radicals by enhancement of SOD activity and reduction of malondialdehyde contents in the brain [36]. In agreement with previous result, our finding showed that treatment of the cells with PF enhanced SOD activity compared to $\mathrm{H}_{2} \mathrm{O}_{2}$-treated control group. Although further studies are required to investigate whether $\mathrm{PF}$ increase activity of catalase or GPx in addition to decomposition of $\mathrm{H}_{2} \mathrm{O}_{2}$, these results support that $\mathrm{PF}$ protected $\mathrm{H}_{2} \mathrm{O}_{2}$-induced cellular damage by regulating the activity of intracellular antioxidant enzymes in C6 glial cells.

Previous study demonstrated that glial cells undergo apoptosis after exposure to $\mathrm{H}_{2} \mathrm{O}_{2}$ [37]. In response to oxidative stress, apoptosis is regulated by $\mathrm{Bcl}-2$ family proteins, which consists of the pro-apoptotic protein, Bax, and the anti-apoptotic protein, Bcl-
2. The Bcl-2 protein improved mitochondrial function, leading to increased ability to withstand oxidative stress [38]. In addition, intracellular ROS levels can be decreased by Bcl-2, which is consistent with an effect of Bcl-2 on ROS clearance [39]. Conversely, Bax expression in cells increased ROS generation and oxidative damage, leading to subsequent activation of caspase-9 and -3 [40,41]. Cleavage of PARP is known to regulate the cell death responses to stimuli caspase activation [42]. Our results showed that the expression of Bcl-2 family protein was modulated by treatment with PF; the apoptosis accelerator, Bax, was downregulated and the apoptosis suppressor, Bcl-2, was up-regulated. Furthermore, Bcl-2/Bax up-regulation by treatment of PF contributes to the suppression of caspases- 9 and -3 activation as well as PARP cleavage in oxidative stress-induced apoptosis. Similar to our study, it has been also demonstrated that PF inhibited the kainicor glutamate-induced apoptosis by up- or down-regulation of these apoptosis-associated proteins (Bcl-2, Bcl-xL, Bax, Bad, caspase-3, and -9) [43,44].

Recently, increasing evidences have suggested that MAPK family, such as JNK and ERK1/2, play crucial roles in regulation of apoptosis, inflammation, oxidative stress, and neuronal dysfunction $[45,46]$. The $\mathrm{H}_{2} \mathrm{O}_{2}$ can stimulate ROS production, which participates in the activation of MAPK signaling pathway in neuronal and glial cells $[47,48]$. To determine whether PF protects glial cell death via modulation of MAPK signaling pathway against $\mathrm{H}_{2} \mathrm{O}_{2-}$ indcued oxidative stress, we analyzed protein expression levels of phospho JNK and phospho ERK1/2. In our study, pretreatment with PF suppressed the $\mathrm{H}_{2} \mathrm{O}_{2}$-induced phosphorylation of JNK and ERK1/2. Previous studies also reported that PF reduced the phospho p38 protein expression levels in AD mice [49]. Furthermore, $\mathrm{PF}$ protects against $\mathrm{H}_{2} \mathrm{O}_{2}$-induced p38 and ERK phosphorylation in human retinal pigment epithelium cells [50], indicating that PF may partially support protective effect on glial cell death via regulation of MAPK activation.

Several in vivo studies demonstrated that orally administration of PF has neuroprotective effects. In rat models, PF administration attenuated cognitive deficits induced by scopolamine [51]. In addition, supplementation of PF significantly alleviated the neurotoxic effect through regulation of neurotransmitters and hormones in rat serum and brain [52]. According to previous studies, PF was detectable immediately in the cortex and hippocampus of rats after intravenous administration of Paeoniae Radix extract containing PF [53,54]. Moreover, PF could quickly penetrate through the blood-brain-barrier to reach the brain region and maintain a high concentration [55], supporting that PF distributes to protective effect on glial cells against oxidative stress.

In conclusion, PF increased the cell viability and decreased the $\mathrm{LDH}$ release as well as ROS production induced by $\mathrm{H}_{2} \mathrm{O}_{2}$ in $\mathrm{C} 6$ glial cells. This was further confirmed by evaluating the antioxidant enzyme activity and apoptosis-related protein expressions, which are considered to be increased to potentiate the elimination of ROS. PF could improve the activity of SOD in $\mathrm{H}_{2} \mathrm{O}_{2}$-treated $\mathrm{C} 6$ 
glial cells. Additionally, treatment with PF was involved in the upregulation of $\mathrm{Bcl}-2 / \mathrm{Bax}$ ratio and down-regulation of caspase-9, -3 , and PARP, indicating that PF may influence the apoptotic signaling pathway via the regulation of the caspase cascade and PARP activation. The protective effect of PF on glial cell damage may, at least partially, be associated with the inhibition of $\mathrm{H}_{2} \mathrm{O}_{2}$ mediated activation of MAPK signaling pathway, as shown by down-regulation of phospho JNK and phospho ERK1/2. Although further study to clarify the neuroprotective effect and absorption of PF administration in vivo model is needed, PF has potential therapeutic value in the progression of neurodegenerative diseases.

Acknowledgments This research was supported by Basic Science Research Program through the National Research Foundation of Korea (NRF) funded by the Ministry of Education [2018R1A6A3A01011960].

\section{References}

1. Halliwell B (1992) Reactive oxygen species and the central nervous system. J Neurochem 59: 1609-1623

2. Bains JS, Shaw CA (1997) Neurodegenerative disorders in humans: the role of glutathione in oxidative stress-mediated neuronal death. Brain Res Rev 25: 335-358

3. Sies H (2017) Hydrogen peroxide as a central redox signaling molecule in physiological oxidative stress: oxidative eustress. Redox Biol 11: 613619

4. Maragakis NJ, Rothstein JD (2006) Mechanisms of disease: astrocytes in neurodegenerative disease. Nat Clin Pract Neurol 2: 679-689

5. Shimohama S (2000) Apoptosis in Alzheimer's disease-an update. Apoptosis 5: 9-16

6. Takata K, Kitamura Y, Yanagisawa D, Morikawa S, Morita M, Inubushi T, Tsuchiya D, Chishiro S, Saeki M, Taniguchi T, Shimohama S, Tooyama I (2007) Microglial transplantation increases amyloid-beta clearance in Alzheimer model rats. FEBS Lett 581: 475-478

7. Lopategui Cabezas I, Herrera Batista A, Penton Rol G (2014) The role of glial cells in Alzheimer's disease: potential therapeutic implications. Neurologlia 29: 305-309

8. Xiao L, Wang YZ, Liu J, Luo XT, Ye Y, Zhu XZ (2005) Effects of paeoniflorin on the cerebral infarction, behavioral and cognitive impairments at the chronic stage of transient middle cerebral artery occlusion in rats. Life Sci 78: 413-420

9. Ohta H, Matsumoto K, Shimizu M, Watanabe H (1994) Paeoniflorin attenuates learning impairment of aged rats in operant brightness discrimination task. Pharmacol Biochem Behav 49: 213-217

10. Mao QQ, Zhong XM, Li ZY, Huang Z (2011) Paeoniflorin protects against NMDA-induced neurotoxicity in PC12 cells via $\mathrm{Ca}^{2+}$ antagonism. Phytother Res 25: 681-685

11. Lee G, Joo JC, Choi BY, Lindroth AM, Park SJ, Park YJ (2016) Neuroprotective effects of Paeonia lactiflora extract against cell death of dopaminergic SH-SY5Y cells is mediated by epigenetic modulation. BMC Complement Altern Med 16: 208

12. Kim SH, Lee MK, Lee KY, Sung SH, Kim J, Kim YC (2009) Chemical constituents isolated from Paeonia lactiflora roots and their neuroprotective activity against oxidative stress in vitro. J Enzyme Inhib Med Chem 24: $1138-1140$

13. Mosmann T (1983) Rapid colorimetric assay for cellular growth and survival: application to proliferation and cytotoxicity assays. J Immunol Methods 65: 55-63

14. Racher AJ, Looby D, Griffiths JB (1990) Use of lactate dehydrogenase release to assess changes in culture viability. Cytotechnology 3: 301-307
15. Cathcart R, Schwiers E, Ames BN (1983) Detection of picomole levels of hydroperoxides using a fluorescent dichlorofluorescein assay. Anal Biochem 134: 111-116

16. Islam MT (2017) Oxidative stress and mitochondrial dysfunction-linked neurodegenerative disorders. Neurol Res 39: 73-82

17. Rodríguez JJ, Olabarria M, Chvatal A, Verkhratsky A (2009) Astroglia in dementia and Alzheimer's disease. Cell Death Differ 16: 378-385

18. Bronstein DM, Perez-Otano I, Sun V, Mullis Sawin SB, Chan J, Wu GC, Hudson PM, Kong LY, Hong JS, McMillian MK (1995) Glia-dependent neurotoxicity and neuroprotection in mesencephalic cultures. Brain Res 704: 112-116

19. Ramalingam M, Kim SJ (2016) Insulin involved Akt/ERK and Bcl-2/ Bax pathways against oxidative damages in C6 glial cells. J Recept Signal Transduct Res 36: 14-20

20. Rossi DJ, Brady JD, Mohr C (2007) Astrocyte metabolism and signaling during brain ischemia. Nat Neurosci 10: 1377-1386

21. Shibata N, Kobayashi M (2008) The role for oxidative stress in neurodegenerative diseases. Brain Nerve 60: 157-170

22. Makar TK, Nedergaard M, Preuss A, Gelbard AS, Perumal AS, Cooper AJL (1994) Vitamin E, ascorbate, glutathione disulfide, and enzymes of glutathione metabolism in cultures of chick astrocytes and neurons: evidence that astrocytes play an important role in antioxidative processes in the brain. J Neurochem 62: 45-53

23. Delacourte A (1990) General and dramatic glial reaction in Alzheimer brain. Neurology 40: 33-37

24. Winterbourn CC (2013) The biological chemistry of hydrogen peroxide. Methods Enzymol 528: 3-25

25. Hamdi Y, Masmoudi-Kouki O, Kaddour H, Belhadj F, Gandolfo P, Vaudry D, Mokni M, Leprince J, Hachem R, Vaudry H, Tonon MC, Amri M (2011) Protective effect of the octadecaneuropeptide on hydrogen peroxide-induced oxidative stress and cell death in cultured rat astrocytes. J Neurochem 118: 416-428

26. Wu YM, Jin R, Yang L, Zhang J, Yang Q, Guo YY, Li XB, Liu SB, Luo $\mathrm{XX}$, Zhao MG (2013) Phospyatidylinositol 3 kinase/protein kinase B is responsible for the protection of paeoniflorin upon $\mathrm{H}_{2} \mathrm{O}_{2}$-induced neural progenitor cell injury. Neuroscience 240: 54-92

27. $\mathrm{Li} \mathrm{P}, \mathrm{Li} \mathrm{Z}$ (2015) Neuroprotective effect of paeoniflorin on $\mathrm{H}_{2} \mathrm{O}_{2}$-induced apoptosis in $\mathrm{PC} 12$ cells by modulation of reactive oxygen species and the inflammatory response. Exp Ther Med 9: 1768-1772

28. Lee SM, Yoon MY, Park HR (2008) Protective effects of Paeonia lactiflora Pall on hydrogen peroxide-induced apoptosis in PC12 cells. Biosci Biotechnol Biochem 72: 1272-1277

29. Whittemore ER, Loo DT, Cotman CW (1994) Exposure to hydrogen peroxide induces cell death via apoptosis in cultured rat cortical neurons. Neuroreport 5: 1485-1488

30. Jang JH, Surh YJ (2001) Protective effects of resveratrol on hydrogen peroxide-induced apoptosis in rat pheochromocytoma (PC12) cells. Mutat Res 496: 181-190

31. Roychowdhury S, Wolf G, Keihoff G, Bagchi D, Horn T (2001) Protection of primary glial cells by grape seed proanthocyanidin extract against nitrosative/oxidative stress. Nitric Oxide 5: 137-149

32. Li CR, Zhou Z, Zhu D, Sun YN, Dai JM, Wang SQ (2007) Protective effect of paeoniflorin on irradiation-induced cell damage involved in modulation of reactive oxygen species and the mitogen-activated protein kinases. Int J Biochem Cell Biol 39: 426-438

33. Kwon SH, Hong SI, Ma SX, Lee SY, Jang CG (2015) 3',4',7trihydroxyflavone prevents apoptotic cell death in neuronal cells from hydrogen peroxide-induced oxidative stress. Food Chem Toxicol 80: 4151

34. Bray RC, Cockle SA, Fielden EM, Roberts PB, Rotilio G, Calabrese L (1974) Reduction and inactivation of superoxide dismutase by hydrogen peroxide. Biochem J 139: 43-48

35. Li W, Qi Z, Wei Z, Liu S, Wang P, Chen Y, Zhao Y (2015) Paeoniflorin inhibits proliferation and induces apoptosis of human glioma cells via microRNA-16 upregulation and matrix metalloproteinase-9 downregulation. 
Mol Med Rep 12: 2735-2740

36. Mahesh R, Kim SJ (2009) The protective effect of insulin on hydrogen peroxide-induced oxidative stress in $\mathrm{C} 6$ glial cells. Biomol Ther 17: $395-402$

37. Richter-Landsberg C, Vollgraf U (1998) Mode of cell injury and death after hydrogen peroxide exposure in cultured oligodendroglia cells. Exp Cell Res 244: 218-229

38. Susnow N, Zeng L, Margineantu D, Hockenbery DM (2009) Bcl-2 family proteins as regulators of oxidative stress. Semin Cancer Biol 19: 42-49

39. Kane DJ, Sarafian TA, Anton R, Hahn H, Gralla EB, Valentine JS, Ord T, Bredesen DE (1993) Bcl-2 inhibition of neural death: decreased generation of reactive oxygen species. Science 262: 1274-1277

40. Kirkland RA, Saavedra GM, Cummings BS, Franklin JL (2010) Bax regulates production of superoxide in both apoptotic and nonapoptotic neurons: role of caspases. J Neurosci 30: 16114-16127

41. Jiang X, Wang X (2004) Cytochrome C-mediated apoptosis. Annu Rev Biochem 73: 87-106

42. Chaitanya GV, Alexander JS, Babu PP (2010) PARP-1 cleavage fragments: signatures of cell-death proteases in neurodegeneration. Cell Commun Signal 8: 31

43. Sun R, Wan K, Wu D, Li X, Ou Y (2012) Protective effect of paeoniflorin against glutamate-induced neurotoxicity in $\mathrm{PC} 12$ cells via Bcl-2/Bax signal pathway. Folia Neuropathol 50: 270-276

44. Wu YM, Xu HP, Wang CT, Yang H, Ju G (2002) Protective effects of paeoniflorin on cultured cortical neurons of mice. Chin. J Pharmacol Toxicol 16: 172-175

45. Dutta K, Ghosh D, Basu A (2009) Curcumin protects neuronal cells from Japanese encephalitis virus-medicated cell death and also inhibits infective viral particle formation by dysregulation of ubiquitinproteasome system. J Neuroimmune Pharmacol 4: 328-337

46. Patraca I, Martínez N, Busquets O, Martí A, Pedrós I, Beas-Zarate C, Marin M, Ettcheto M, Sureda F, Auladell C, Camins A, Folch J (2017) Anti-inflammatory role of leptin in glial cells through p38 MAPK pathway inhibition. Pharmacol Rep 69: 409-418

47. Kwon DY, Kim SJ, Lee JW, Kim YC (2010) Comparison of hydroxyl radial, peroxyl radical, and peroxynitrite scavenging capacity of extracts and active components from selected medicinal plants. Toxicol Res 26: 321-327

48. Lin X, Wu S, Wang Q, Shi Y, Liu G, Zhi J, Wang F (2016) Saikosaponin-D reduces $\mathrm{H}_{2} \mathrm{O}_{2}$-indcued $\mathrm{PC} 12$ cell apoptosis by removing ROS and blocking MAPK-dependent oxidative damage. Cell Mol Neurobiol 36: 1365-1375

49. Gu X, Cai Z, Cai M, Liu K, Zhang Q, Tan J, Ma Q (2016) Protective effect of paeoniflorin on inflammation and apoptosis in the cerebral cortex of a transgenic mouse model of Alzheimer's disease. Mol Med Rep 13: 2247-2252

50. Wankun X, Wenzhen Y, Min Z, Weiyan Z, Huan C, Wei E, Lvzhen H, $\mathrm{Xu}$ Y, Xiaoxin L (2011) Protective effect of paeoniflorin against oxidative stress in human retinal pigment epithelium in vitro. Mol Vis 17: 3512-3522

51. Ohta H, Ni JW, Matsumoto K, Watanabe H, Shimizu M (1993) Paeony and its major constituent, paeoniflorin, improve radial maze performance impaired by scopolamine in rats. Pharmacol Biochem Behav 45: 719723

52. Sun L, Chen Y, Hou C, Sun X, Wang Z, Li S, Lv M, Chen X (2018) Neuroprotective effect of total glycosides from paeonies against neurotoxicity induced by strychnos alkaloids related to recovering the levels of neurotransmitters and neurodendocrine hormones in rat serum and brain. RSC Adv 8: 29210-29219

53. Cao C, He X, Wang W, Zhang L, Lin H, Du L (2006) Kinetic distribution of paeoniflorin in cortex of normal and cerebral ischemiareperfusion rats after intravenous administration of Paeoniae Radix extract. Biomed Chromatogr 20: 1283-1288

54. Tanaka T, Kataoka M, Tsuboi N, Kouno I (2000) New monoterpene glycoside esters and phenolic constituents of Paeoniae radix, and increase of water solubility of proanthocyanidins in the presence of paeoniflorin. Chem Pharm Bull 48: 201-207

55. He X, Xing D, Ding Y, Li Y, Xiang L, Wang W, Du, L (2004) Determination of paeoniflorin in rat hippocampus by high-performance liquid chromatography after intravenous administration of Paeoniae Radix extract. J Chromatogr B Analyt Technol Biomed Life Sci 802: 277-281 